\title{
PAINTED REDSTART AT PINAWA,MB: FIRST RECORD FOR THE PRAIRIE PROVINCES
}

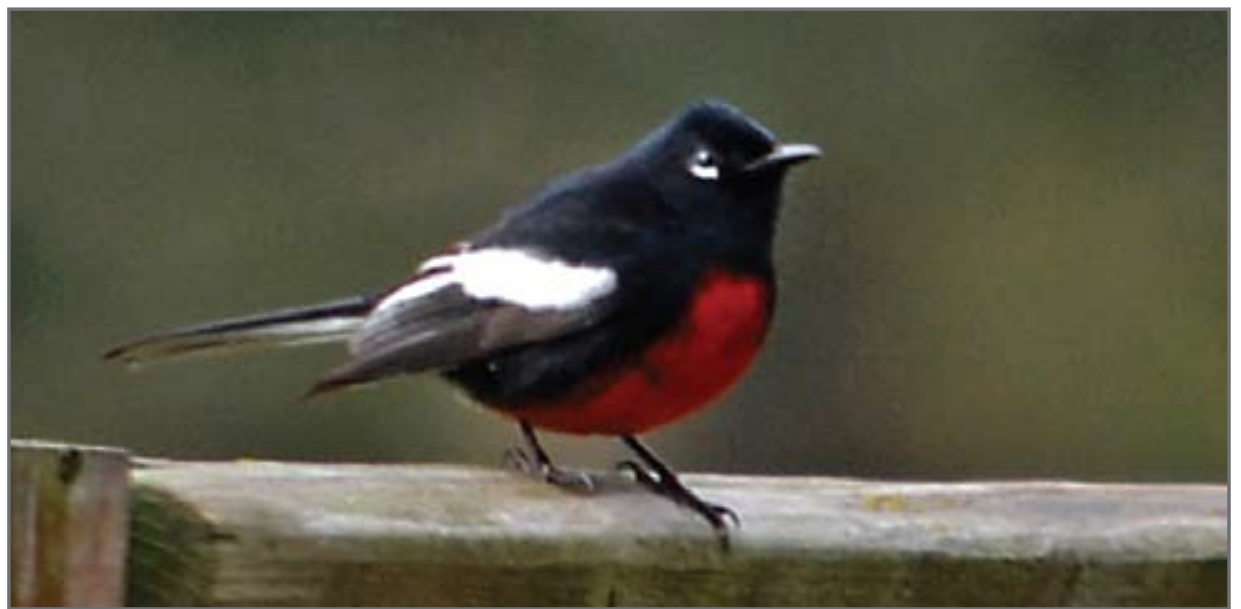

FIGURE 1: The first day: Painted Redstart pauses briefly on a garden fence in Pinawa, MB, October 27, 2016. Photo credit: Jack Frederick

\section{Peter Taylor}

P.O. Box 597, Pinawa, MB ROE 1 L0

taylorp@granite.mb.ca

On the morning of October 27, 2016, Pinawa residents Jack and Val Frederick twice observed a beautiful, unfamiliar warbler in their garden. They photographed and identified it as a Painted Redstart (Myioborus pictus) - an outstanding rarity anywhere in Canada or indeed the northern U.S.A. They contacted Anita Drabyk, who relayed the news to me and a few other birders; altogether six of us saw the bird that day, and many more photographs were taken (Fig. 1).

News of the bird was posted that evening to Manitobabirds, a provincial online discussion group, after some discussion of the large number of visitors it was likely to attract. Since it was evidently moving around the neighbourhood, general locality information was provided, rather than a specific address, to avoid undue pressure on individual Pinawa residents. The bird aroused much interest, attracting an estimated 70 to 100 birders and photographers from as far afield as Brandon and Minnedosa during the 12 days of its recorded stay. This number is small in comparison to a similar rarity in more populous regions, but places it near the top of single-bird events in Manitoba. Most visitors were successful in their quest and many residents willingly opened their backyards to help strangers view the bird. The final sightings were on November 7; the bird was not located by intensive searching on November 8 , nor on any subsequent visits.

\section{Identification}

The Painted Redstart is a fairly large, slightly long-tailed warbler; the Pinawa bird was in unmistakable adult plumage (sexes are similar). Extensive white areas in the wings and tail contrasted with the black plumage, especially in flight. The highlight was a large, rich red patch on the lower breast and belly; a white fleck below each eye was also noted (Figs. 1 to 3). Moult from juvenile to Basic I plumage is typically complete by September, so it is possible that this Painted Redstart was a hatching-year bird. ${ }^{1}$ Though it was mostly silent, its characteristic siskin-like call was heard on several occasions, sometimes in extended bouts of repeated calling, both while perched and in flight.

\section{Normal range and habitat}

The Painted Redstart's breeding range extends from parts of southern Arizona and southern New Mexico through Mexico to northern Nicaragua. Breeding is rare, local, and apparently irregular in southern parts of California, west Texas, and possibly Nevada and Utah (mostly in and near Zion National Park). ${ }^{1-4}$ Northern populations are mostly migratory, but small numbers overwinter in southern Arizona. ${ }^{1}$ Away from the known breeding localities, 100+ records for California occurred primarily in fall and winter months in the southern third of the state. $^{5}$

Breeding and wintering habitats are mostly oak, oak-pine, and oakjuniper woodlands, often in riparian settings, and tending to favour lower elevations in winter. ${ }^{1}$

\section{Vagrancy pattern}

Individuals have previously been found on rare occasions in fall as far north as British Columbia, Montana, Minnesota, Michigan, southern Ontario, Ohio, New York, and Massachusetts, and in spring in Wisconsin. ${ }^{1,6}$ As expected, occurrence is more frequent in states adjoining the breeding range, especially southern California but including Kansas and Colorado, and there is also a small cluster of records in the Gulf States and Georgia but excluding Florida. 1,6,7 Curiously, there is a broad contiguous band of states with no records across the entire continent from Oregon and 
Washington through the Mississippi Valley to the Carolinas and several other Atlantic states. ${ }^{6}$

The first Canadian record of a Painted Redstart occurred at the community of Balsam, north of Pickering, Ontario in 1971; the bird was first observed on November 4, captured on November 15, and survived in captivity until at least January $1972.8,9$ In their account of this record, Speirs and Pegg cited previous northern records at: Marblehead Neck, Massachusetts on October 18-19, 1947; Madison, Wisconsin on April 22, 1965; and near Cleveland, Ohio on November 15-22, 1970. ${ }^{8}$ The second Canadian record was a multiple-observer sighting, supported by detailed descriptions, at West Vancouver, British Columbia on November 4, 1973. ${ }^{10}$ The Pinawa bird appears to constitute Canada's third record, after a 43-year gap, and is the first to be recorded in the Prairie Provinces.

New York State's first Painted Redstart was discovered at a feeder at Dansville, Livingston County on December 14, 1979 and survived there for about six weeks; its depredated remains were discovered on January $26,1980 .{ }^{11}$ The first state record for Michigan, at Gladstone Bluff, Delta County on November 12-13, 1983 was confirmed by photographs. ${ }^{12}$ Coincident with the Pinawa bird, a Painted Redstart was photographed near Marathon, Wisconsin on November 1, 2016, furnishing (if ratified) a second state record..$^{13}$ In Minnesota, a single-observer sighting at Mille Lacs Lake on September 30, 1992 was accepted by the state records committee on the strength of a detailed sketch and description. ${ }^{14,15}$ A second Minnesota sighting on May 25, 2007 was not accepted because of inadequate details. ${ }^{16}$ Montana's first Painted Redstart

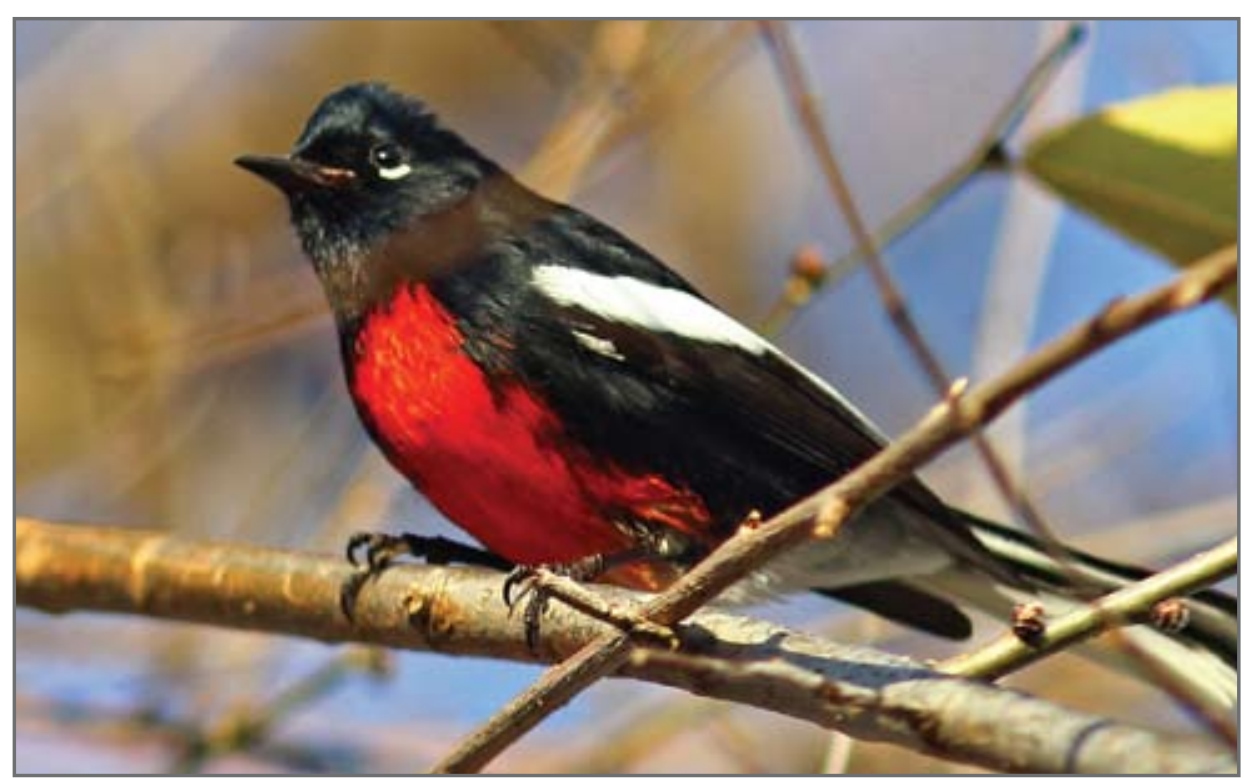

FIGURE 2: The last day: Painted Redstart aglow in the sunshine in Pinawa, MB, November 7, 2016. Photo credit: Josiah Van Egmond

was seen at Clinton on November 7-13, 1987 and documented with photographs. ${ }^{17-19}$ A report from Nevada, Missouri on October 19, 1986 appears not to have been accepted, because the species is absent from the current state checklist. ${ }^{20,21}$

Seven of the 10 accepted northerly records summarized above occurred between October 18 and November 22. The Pinawa, Manitoba record (October 27 to November $7,2016)$ fits this pattern exactly, and is consistent with misoriented migration followed by establishment of a feeding area (see below). Given this known pattern of long-distance vagrancy, the provenance of the Pinawa bird is not in doubt, i.e., there is no evidence of, nor any need to invoke, prior captivity or humanassisted migration.

\section{Observations on feeding territory and foraging in Pinawa}

During its 12-day recorded stay, this vagrant Painted Redstart was observed repeatedly within a small area of Pinawa, centred on two residential streets (Landsdowne Avenue and Stanley Avenue), associated gardens, and a narrow, intervening buffer strip of natural woodland. The estimated minimum size of this feeding area (polygon formed by outlying sightings) is 5 ha.

One attraction seemed to be delayed leaf fall of several cultivated trees (e.g., willow, Siberian elm, and silver maple) and vines (e.g., bittersweet), whereas leaf loss was essentially complete in native deciduous trees and shrubs. The trees with persisting foliage appeared to provide the best available foraging for lingering invertebrate prey during the first week. The bird was also noted foraging at all levels from ground to canopy in bare trees and shrubby tangles, and it also perched frequently on roofs and eavestroughs. Its short-term prospects were greatly enhanced by unseasonably mild weather, with daytime temperatures often well into the teens and occasionally the low 20s Celsius. Conditions were generally cloudy for the first week and sunny thereafter, with minimal overnight frost. On November 4, Michael Loyd and others observed the Painted Redstart catch two housefly-sized insects during a sunny spell. On November 6, Christian 
Artuso saw it foraging, nuthatch-like, in bark crevices on a leafless tree (Fig.

3). Except for the bird's apparent preference for lingering foliage while available, these observations are in broad agreement with the statement by Barber et al. that Painted Redstarts forage from ground level to tree tops, predominantly on small and large twigs, trunks of trees, and to a lesser extent on leaves. ${ }^{1}$

The bird's movements were less "butterfly-like" than those of the American Redstart (Setophaga ruticilla), which is not a close relative. Nevertheless, several observers noted both wing-drooping and tail-fanning movements, displaying the conspicuous white markings, as it foraged. The context of these movements (e.g., response to potential competitors or predators; prey flushing) was not determined.

Although many birds of other species were attracted to feeders and natural foods within its territory, the Painted Redstart rarely mixed with them and apparently did not visit feeders. It was noted only in brief association with Black-capped Chickadees (Poecile atricapillus) and once with a late-migrating Yellow-rumped Warbler (Setophaga coronate). It shared treetop feeding

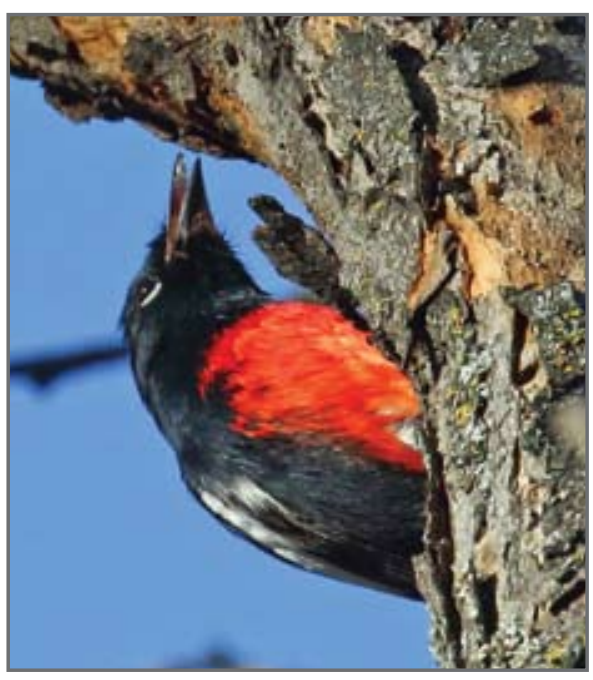

FIGURE 3: Painted Redstart foraging in bark crevices on a leafless tree in Pinawa, MB, November 6, 2016. Photo credit: Christian Artuso areas with both Red-breasted Nuthatches (Sitta canadensis) and White-breasted Nuthatches (S. carolinensis) without obvious interaction. Solitary behaviour seems to be the norm for vagrant Painted Redstarts, though the West Vancouver individual associated with chickadees and other small birds. ${ }^{10}$

The Painted Redstart appeared lively and flew strongly throughout its stay in Pinawa. One can only speculate on the reasons for its disappearance during an unbroken mild spell; possibilities include predation or accident (such as a window strike), ongoing migration or wandering, or demise through declining physical condition as the insect supply dwindled.

\section{Acknowledgements}

I thank Jack and Val Frederick for their timely reporting of this exceptional rarity, and the many residents and visiting birders who made it a positive occasion for both the local and birding communities. I also acknowledge Christian Artuso, Anita Drabyk, and Rudolf Koes for helpful comments on draft manuscripts. Christian Artuso, Jack Frederick, and Josiah Van Egmond kindly allowed me to include their photographs with this article, and Michael Loyd shared observations and photographs.

NOTE: All web pages cited below were accessed and verified on December 20, 2016.

1. Barber DR, Barber PM, Jablonski PG (2000) Painted Redstart (Myioborus pictus), The Birds of North America (P. G. Rodewald, Ed.). Ithaca: Cornell Lab of Ornithology; retrieved from the Birds of North America: https://birdsna.org/ Species-Account/bna/species/paired.

2. Floyd T, Elphick CS, Chisholm G, Mack K, Elston R, Ammon, EM, Boone JD (2007) Atlas of the breeding birds of Nevada. University of Nevada Press, Reno NV.

3. Utah Bird Records Committee (2016)

Documented sightings of Utah review species: flycatchers to warblers, www.utahbirds.org/
RecCom/UBRC_SightingsIndex.html.

4. Wauer RH (1969) Recent bird records from the Virgin River valley of Utah, Arizona, and Nevada, Condor, 71:331-335.

5. California Bird Records Committee (undated) Rare birds of California [updated

to 2006]: Painted Redstart Myioborus pictus (Swainson, 1829). http://www. wfopublications.org/Rare_Birds/Painted_ Redstart/Painted_Redstart.html.

6. Sohl TL (undated) Painted Redstart range map. http://sdakotabirds.com/species/maps/ painted_redstart_map.htm.

7. Kansas Bird Records Committee (2003 and 2011) Annual reports. www.ksbirds.org/kos/ kos_kbrc.htm.

8. Speirs JM, Pegg E (1972) First record of Painted Redstart (Setophaga picta) for Canada. Auk, 89:898.

9. Wormington A, Curry RH (1990) Ontario Bird Records Committee Report for 1989. Ontario Birds, 8:4-33.

10. Weber WC, Kautesk B (1975) A sight record of the Painted Redstart near Vancouver, British Columbia. Western Birds, 6:67.

11. Spahn R (1980) Photographs of New York State rarities: 35 Painted Redstart. Kingbird, 30:67.

12. Michigan Bird Records Committee (2016) Painted Redstart. http://mibirdrecords.com/ painted-redstart.

13. Backus M (2016) E-bird checklist No. S32331288. https://ebird.org/ebird/view/ checklist/S32331288.

14. Geerts M (1993) Minnesota's first Painted Redstart. The Loon, 65:49.

15. Eckert KR (1993) Proceedings of the Minnesota Ornithological Records Committee. The Loon, 65:33-36.

16. Svingen, PH (2008) Proceedings of the Minnesota Ornithologists' Union Records Committee. The Loon, 80:5-13.

17. Rogers TR (1988). Fall 1987: Northern Rocky Mountain-Intermountain Region. American Birds, 42:104-108.

18. Montana Bird Distribution Committee (2012). P.D. Skaar's Montana bird distribution, 7th edition. Montana Natural Heritage Program, Helena MT.

19. Marks JS, Hendricks P, Casey D (2016) Birds of Montana (sponsored by Montana Audubon). Buteo Books, Arrington VA.

20. Peterjohn BG (1987) Fall 1986:

Middlewestern Prairie Region. American Birds 41:93-99.

21. The Audubon Society of Missouri (2016) Annotated checklist of Missouri birds. www. mobirds.org/Birds/MOChecklist.aspx. 